\title{
Modeling mGluR1 mediated synaptic depression in cerebellar Purkinje cells
}

\author{
Yizhen $\mathrm{Su}^{1}, \mathrm{HuO} \mathrm{Lu}^{2^{*}}$ \\ From The Twenty Third Annual Computational Neuroscience Meeting: CNS*2014 \\ Québec City, Canada. 26-31 July 2014
}

We have previously successfully simulated mGluR1 mediated sEPSP based on experimental data. This effect is associated with parallel fiber - Purkinje cell LTD [1-3]. The mGluR1 mediated sEPSP is generated by calcium signaling through the TRPC channel which is crucial in cerebellar LTD induction [4]. Behavior study using mutant mice that lack this type of LTD has shown no motor learning impairment [5]. We hypothesize that cerebellar TRPC mediated synaptic depression shifts the excitatory and inhibitory balance to down regulate ongoing simple-spike activity. To test our hypothesis we modified our previous model of a Purkinje cell to have TRPC channel current signal linked to the AMPA channel conductance through Kinetikit.
The synaptic depression mediated by TRPC channel current is successfully simulated in the local model. Synchronized train stimulation to the spines in the full model of Purkinje cell were able to cause the cell to fire then followed by a gap in spiking caused by the reduction in the gmax of AMPA channels. Once the TRPC current passed the rising phase, the firing resumed. This model will be used to guide the in vitro experiments to study the interaction of TRPC current mediated depression with simple spike activities. Once the second messenger (s) and the delay time of the plastic effects are know, this model can be further used to study the function of cerebellar LTD.

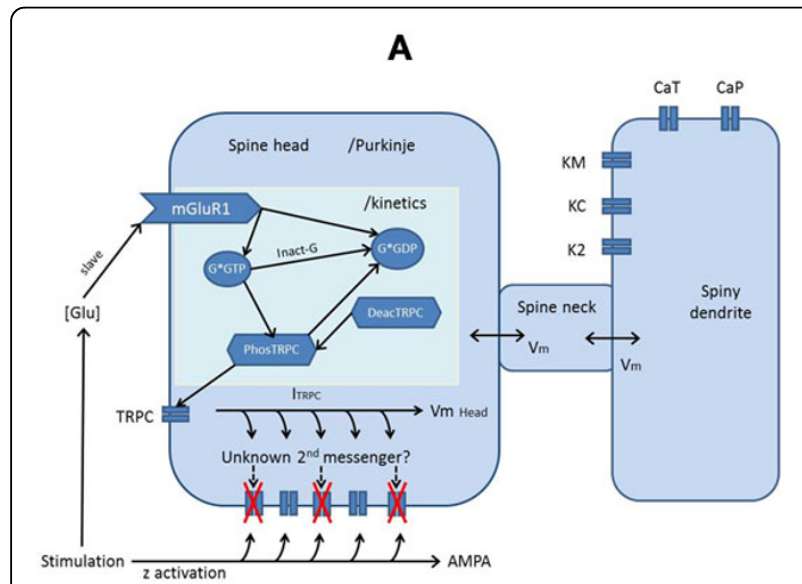

B
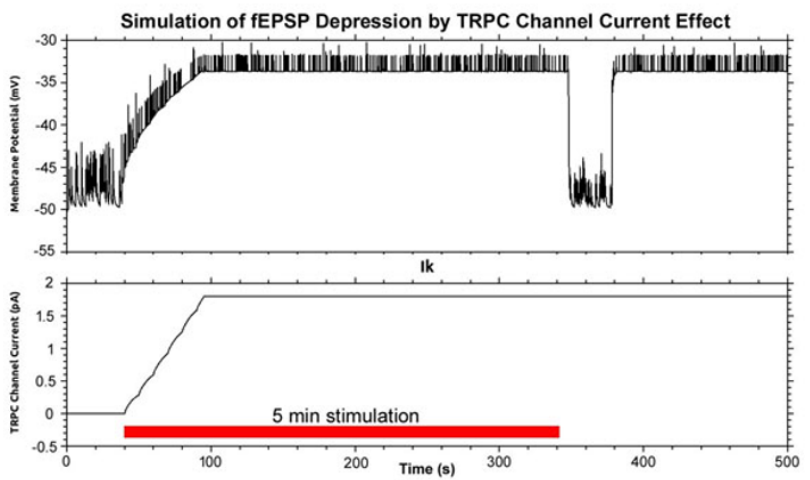

Figure 1 Local model constructed to simulate fEPSP depression triggered by TRPC channel current. A. TRPC channel current (IK) increase due to activation of mGluR1 is linked to AMPA channel conductance (gmax) to simulate the decrease of the channel density. B. fEPSPs are evoked randomly at $1 \mathrm{~Hz}$ to monitor the amplitude change of the depression effect caused by TRPC current (IK).

\footnotetext{
* Correspondence: huolu@pcom.edu

${ }^{2}$ Department of Biomedical Sciences, Philadelphia College of Osteopathic

Medicine, Suwanee, GA 30024, USA

Full list of author information is available at the end of the article
}

() BioMed Central

(c) 2014 Su and Lu; licensee BioMed Central Ltd. This is an Open Access article distributed under the terms of the Creative Commons Attribution License (http://creativecommons.org/licenses/by/4.0), which permits unrestricted use, distribution, and reproduction in any medium, provided the original work is properly cited. The Creative Commons Public Domain Dedication waiver (http:// creativecommons.org/publicdomain/zero/1.0/) applies to the data made available in this article, unless otherwise stated. 


\section{Acknowledgements}

We thank the support of CSO fund from PCOM to provide computers for simulation. We also thank Drs. Cornelis and Beeman for their help through genesis-sim-users@lists.sourceforge.net.

\section{Authors' details}

'Doctor of Osteopathic Medicine - GA-Philadelphia College of Osteopathic Medicine, Suwanee, GA 30024, USA. ²Department of Biomedical Sciences, Philadelphia College of Osteopathic Medicine, Suwanee, GA 30024, USA.

Published: 21 July 2014

\section{References}

1. Huo Lu, C L, Yan Wu, James M Bower: Modeling TRPC1 mediated slow EPSPs in cerebellar Purkinje cells. CNS*2007 2007, Abstract.

2. Jin $Y$, et al: Long-term depression of mGluR1 signaling. Neuron 2007 55(2):277-87.

3. Kim SJ, et al: Activation of the TRPC1 cation channel by metabotropic glutamate receptor mGluR1. Nature 2003, 426(6964):285-91.

4. Kim SJ: TRPC3 channel underlies cerebellar long-term depression. Cerebellum 2013, 12(3):334-7.

5. Schonewille $M$, et al: Reevaluating the role of LTD in cerebellar motor learning. Neuron 2011, 70(1):43-50.

doi:10.1186/1471-2202-15-S1-P110

Cite this article as: Su and Lu: Modeling mGluR1 mediated synaptic depression in cerebellar Purkinje cells. BMC Neuroscience 2014 15(Suppl 1):P110.

\section{Submit your next manuscript to BioMed Central and take full advantage of:}

- Convenient online submission

- Thorough peer review

- No space constraints or color figure charges

- Immediate publication on acceptance

- Inclusion in PubMed, CAS, Scopus and Google Scholar

- Research which is freely available for redistribution

Submit your manuscript at www.biomedcentral.com/submit 